\title{
Final Report for the Atlantic Rim Mule Deer Study
}

Prepared For:

Anardarko Petroleum Company

Houston Corporate Office

1201 Lake Robbins Drive

The Woodlands, TX 77380

Bureau of Land Management

Rawlins Field Office

1300 N. Third

PO Box 2407

Rawlins, WY 82301

Warren E\& P, Inc.

123 West $1^{\text {st }}$ St., Suite 505

Casper, WY 82601

Wyoming Game and Fish Department

5400 Bishop Blvd.

Cheyenne, WY 82006

Prepared By:

Hall Sawyer

Western Ecosystems Technology, Inc.

2003 Central Avenue

Cheyenne, WY 82001

April 2007

QI

737

.055 


\title{
Final Report for the Atlantic Rim Mule Deer Study
}

Prepared For:

\author{
Anardarko Petroleum Company \\ Houston Corporate Office \\ 1201 Lake Robbins Drive \\ The Woodlands, TX 77380
}

\section{Bureau of Land Management}

Rawlins Field Office

$1300 \mathrm{~N}$. Third

PO Box 2407

Rawlins, WY 82301

Warren E\& P, Inc.

123 West $1^{\text {st }}$ St., Suite 505

Casper, WY 82601

Wyoming Game and Fish Department

5400 Bishop Blvd.

Cheyenne, WY 82006

Prepared By:

Hall Sawyer

Western Ecosystems Technology, Inc.

2003 Central Avenue

Cheyenne, WY 82001

April 2007

\author{
BLM Library \\ Denver Federal Center \\ Bldg. 50, OC-521 \\ P.O. Box 25047 \\ Denver, CO 80225
}


Vis adi. MLIE

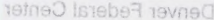

rsà-20, 0e oble

TAOCS X08.00

zSSOB OD rovnaC 


\section{ACKNOWLEDGMENTS}

Anadarko Petroleum Company (APC) and Warren E \& P provided funding for this project. The Wyoming Game and Fish Department (WGFD) and Rawlins Field Office of the Bureau of Land Management (BLM) provided in-kind donations and study direction. We thank Joy Rector (APC), Cathy Flansburg (APC), David Applegate (APC), Scott Hedlund (Warren E \& P), Frank Blomquist (BLM), Mary Read (BLM), Heath Cline (BLM), Bill Rudd (WGFD), Tim Woolley (WGFD), and Greg Hiatt (WGFD) for office and logistical support. Dwight France (France Flying Service) conducted all the relocation flights and Jim Pope (Leading Edge Aviation) provided the helicopter capture service. We appreciate Jack Cobb, John Espy, Mike Sheehan, Chuck Sanger, and Three Forks Ranch for allowing us to access their lands.

\section{TABLE OF CONTENTS}

10 Page

$2.0 \quad$ Study Area................................................... 3

$3.0 \quad$ Objectives................................................. 6

$4.0 \quad$ Methods...................................................... 6

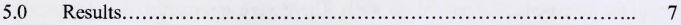

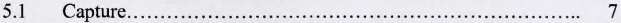

5.2 GPS collars .............................................. 8

5.3 Adult survival and mortality............................. 8

5.4 Seasonal distribution, migration and movement rates........... 9

6.0 Discussion.................................................. 24

$7.0 \quad$ Management Implications....................................... 26

$8.0 \quad$ Literature Cited..................................................... 27 


\subsection{INTRODUCTION}

Increased levels of energy development across southwest Wyoming have created a variety of concerns for fish, wildlife and the habitats they occupy (Bureau of Land Management [BLM] 1998). Impacts include direct and indirect habitat losses that can potentially result in reduced population performance (Sawyer et al. 2006a). Direct habitat loss occurs when native vegetation is converted to access roads, well pads, pipelines, and other project features. Indirect habitat losses occur when wildlife are displaced or avoid areas near infrastructure because of increased levels of human disturbances (e.g., traffic, noise, pollution, human presence). The draft environmental impact statement (DEIS) for the Atlantic Rim Project Area (ARPA) proposes the development of 2,000 natural gas wells, including 1,800 to coal beds and 200 to other formations, at a spacing of up to 80 acres per well (BLM 2005). Mule deer herds in the Atlantic Rim region are among the largest in the Intermountain West and known to migrate up to 60 miles between seasonal ranges (Porter 1999). Maintaining healthy mule deer populations and functional migration routes is a top priority for agencies and the public. In response to the proposed Atlantic Rim Natural Gas Development Project, the BLM, the Wyoming Game and Fish Department (WGFD), Anadarko Petroleum Company (APC), and Warren E \& P, Inc. implemented a cooperative study intended to provide the necessary information to mitigate potential impacts and ensure development plans are environmentally sensitive to mule deer.

This study was designed to have two phases. The first phase of the study was intended to identify seasonal ranges, document migration routes, and estimate survival rates prior to development of the proposed 2,000 natural gas wells. There were approximately 116 natural gas wells completed to coal formations under an exploratory interim drilling program (BLM 2005) in the ARPA during Phase I. Full-scale development was not expected until the summer of 2007, following the Record of Decision on the Final Environmental Impact Statement (BLM 2006). Phase I of the study was expected to last approximately two years (2005 through 2006). Once Phase I was completed, study cooperators were to determine if Phase II was warranted. If conducted, Phase II was envisioned as a long-term ( $>3$ years) study that would occur during or after development to determine if impacts to mule deer from natural gas development occur, including changes in migration routes, habitat use patterns, and survival.

This study was not implemented as a compliance measure; rather it was a cooperative effort among agencies and industry to better understand mule deer ecology in the ARPA. Information from Phase I provides the baseline information necessary to develop energy resources such that important migration routes and seasonal ranges can be protected or minimally impacted. Additionally, Phase I provides the pre-development information needed, should Phase II of the study materialize. This report summarizes work completed in Phase I. 


\subsection{STUDY AREA}

The ARPA is located in southern Carbon County (Figure 1) and encompasses $422 \mathrm{mi}^{2}$ south of I-80, east of WY 789, and north of WY 70 (Figure 2). The ARPA extends approximately 48 miles between Rawlins and Baggs, and contains $64 \%\left(271 \mathrm{mi}^{2}\right)$ federal, $5 \%$ $\left(22 \mathrm{mi}^{2}\right)$ state, and $31 \%\left(129 \mathrm{mi}^{2}\right)$ private lands (BLM 2005). The ARPA is located in the eastern portion of the Baggs herd unit which includes 3 hunt areas $(82,84,100$; Figures 1 and 2 ). The WGFD manages the Baggs herd unit for a post-hunting season population of 18,700 deer, but the estimated herd size has ranged from 20,200 in 2001 to 22,300 in 2005 (Woolley 2005). At the time of this study (2006) there were approximately 116 natural gas wells completed in the ARPA and the DEIS proposed development of up to 2,000 (BLM 2005). The ARPA supports a variety of vegetation types, but is generally characterized by rolling topography, prominent ridges, and dry canyons dominated by sagebrush (Artemisia sp.), black greasewood (Sacrobatus vermiculatus), Utah juniper (Juniperus osteosperma), and other mixed-shrub (Purshia tridentata, Prunus virginiana, Amelanchier alnifolia, Chrysothamnus sp., Cercocarpus sp.) (Photos 1 and 2). Elevations range from 6,300 to 8,300 feet. The ARPA contains 21 livestock allotments totaling 30,462 permitted animal unit months (AUM; BLM 2005). Refer to BLM (2005) for detailed description of study area.

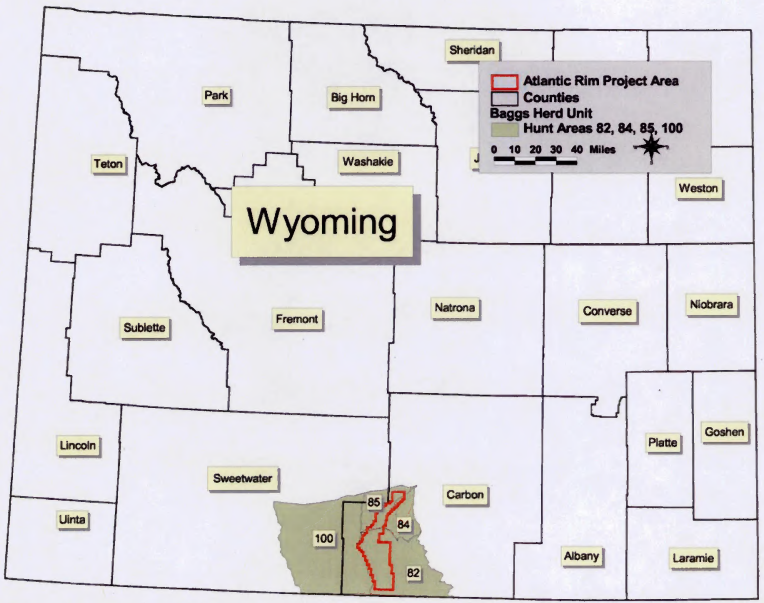

Figure 1. Location of the Baggs Herd Unit and Hunt Areas 82, 84, 85, and 100 relative to the Atlantic Rim Project Area (ARPA) in south-central Wyoming. 


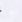




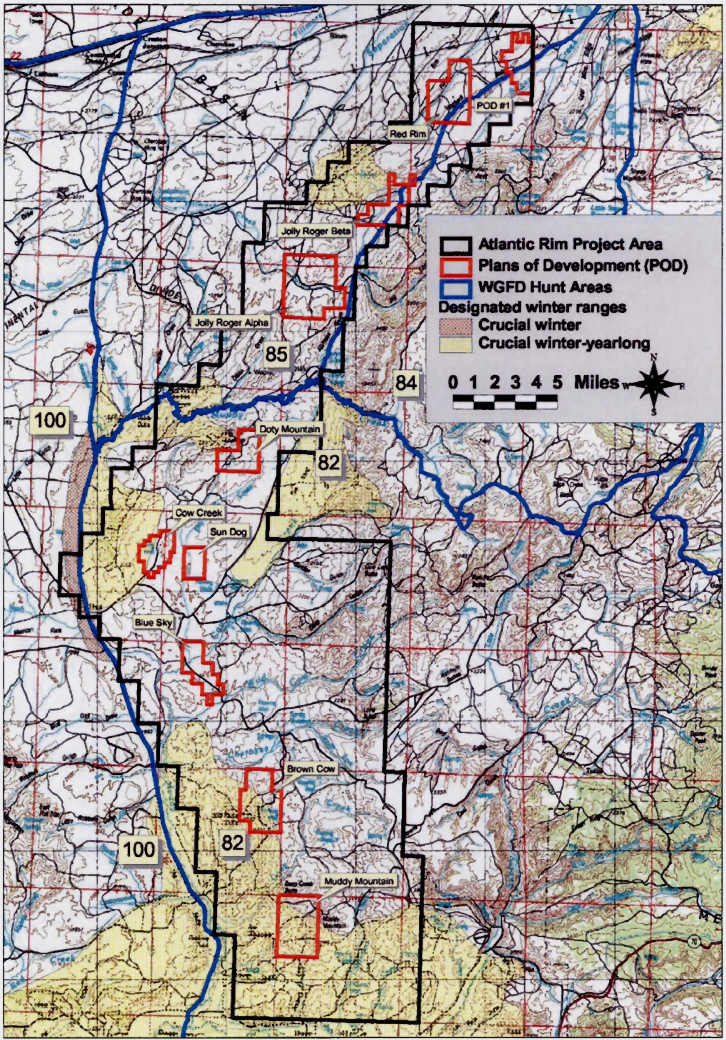

Figure 2. Location of crucial mule deer winter ranges, mule deer hunt areas, and plans of development (POD) in the Atlantic Rim Project Area (ARPA) in south-central Wyoming. 



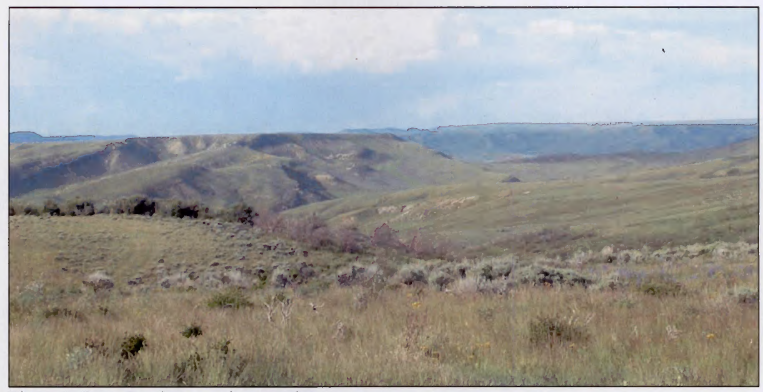

Photo 1. Cow Creek area, view north.

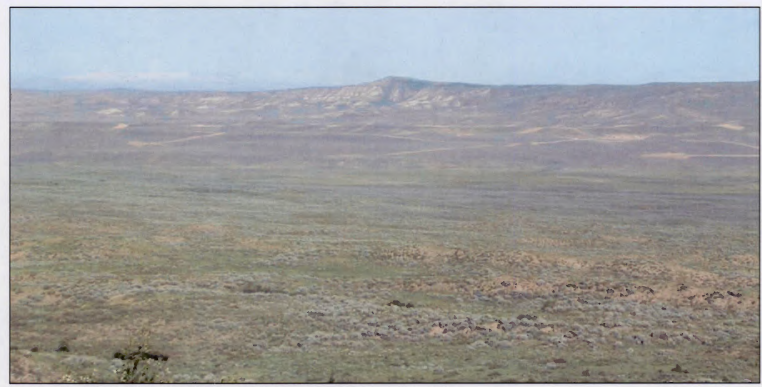

Photo 2. Sand Hills and Doty Mountain, view northwest. 



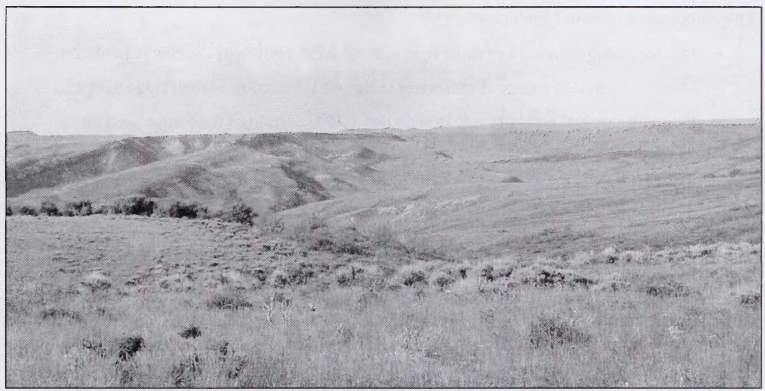

Photo 1. Cow Creek area, view north.

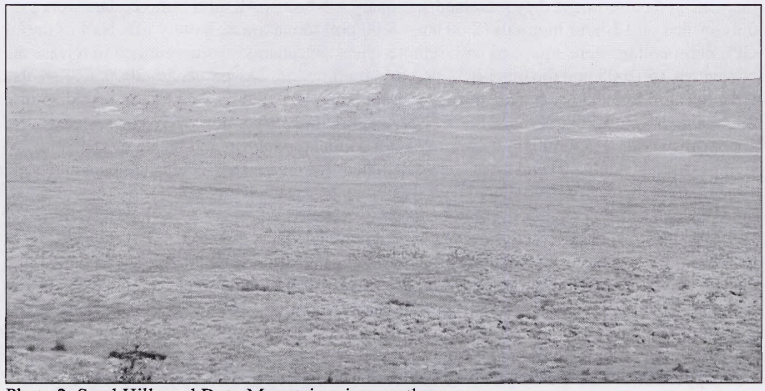

Photo 2. Sand Hills and Doty Mountain, view northwest. 


\subsection{OBJECTIVES}

The objectives of Phase I included:

$>$ Identify seasonal ranges of mule deer in the ARPA portion of the Baggs herd unit.

$>$ Identify migration routes of mule deer in the ARPA portion of the Baggs herd unit.

$>$ Estimate survival rates of mule deer in the ARPA portion of the Baggs herd unit.

\subsection{METHODS}

We used helicopter net-gunning (Leading Edge Aviation, Lewiston, Idaho) techniques to capture adult female mule deer across winter ranges located in or adjacent to the ARPA. We attempted to sample deer in proportion to their numbers across the ARPA, as determined by pre-capture fixed-wing flight and ground surveys. Captured deer were fitted with standard very high frequency (VHF) radio-collars (Advanced Telemetry Systems, Isanti, Minnesota) or global positioning system (GPS) radio-collars (Telonics, Mesa, Arizona) programmed to collect 1 location every 2.5 hours October 1 through June 15, and 1 location every 25 hours June 16 through September 30. This GPS fix schedule was designed to intensify data collection during fall migration, winter, and spring migration while continuing to obtain daily locations during the summer period. All radio-collars were equipped with mortality sensors that changed pulse rate if they remained stationary $>8$ hours. All GPS radio-collars were duty-cycled on 12-hour intervals $(8: 00 \mathrm{am}-8: 00 \mathrm{pm})$ to maximize battery life. Half of the GPS radio-collars were equipped with remote-release mechanisms programmed to release on November 15, 2005 and the other half were programmed for November 15, 2006. Collars that were released in $\mathbf{2 0 0 5}$ or recovered from deer that died were put on a new sample of deer in 2006. Fixed-wing flights (France Flying Service, Rawlins, Wyoming) were conducted approximately once a month to monitor general animal movement and locate mortality signals. Annual adult survival rates were calculated from telemetry records (Kaplan and Meier 1985). The sample of VHF-collared deer was intended to supplement the GPS-collars so that more precise survival estimates could be made.

Data collected from GPS-collars were downloaded and mapped in ArcView (Environmental Systems Research Institute, Redlands, California) to identify seasonal distribution patterns and migration routes. Seasonal distribution patterns were identified by mapping locations of GPS-collared deer during 4 time periods; winter (December 1 - March 30), summer (June 1 - September 30), parturition (June 1- 14), and transition (April 15 - May 15 and October 1 - November 15). Migration routes were identified using 4 basic steps. First, we mapped the movement routes of all GPS-collared deer by simply drawing straight lines between successive locations of each deer. Second, we calculated the rate of movement or velocity of each line segment and created a map of movement routes that had velocities of $0.40 \mathrm{mi} / \mathrm{hr}$ or higher. The $0.40 \mathrm{mi} / \mathrm{hr}$ cut-off was intended to reflect the movement rates that occur in migration corridors and exclude those in summer and winter ranges. Third, we then digitized common migration routes that reflected areas where multiple high-velocity movements occurred. And finally we buffered the common migration routes by $0.25 \mathrm{mi}$.

To help visualize and identify the timing of seasonal migrations we calculated and plotted average daily movement rates for GPS-collared deer. Daily movement rates were 
calculated by averaging the straight-line distances between successive locations during a 3day moving window. The average daily movement rates were then averaged across deer and plotted for those time periods where GPS locations were collected multiple times per day (October 1 - June 15).

\subsection{RESULTS}

\subsection{Capture}

We captured 41 adult female deer across winter ranges located in or adjacent to the ARPA on February 8, 2005. Of the 41 deer, 10 were fitted with standard VHF radio-collars and 31 were equipped with GPS radio-collars (Table 1). We captured an additional 22 adult female deer on December 10, 2005. Of these, 4 were fitted with VHF radio-collars and 18 with GPS radio-collars (Table 1). The 18 GPS collars included 7 from deer that had died; 4 of which were programmed to drop off in November 2005 and 3 in November 2006.

Table 1. List of 63 radiomarked deer in the Atlantic Rim Project Area (ARPA).

\begin{tabular}{|c|c|c|c|c|c|c|c|}
\hline $\begin{array}{l}\text { Deer } \\
\text { ID }\end{array}$ & Frequency & $\begin{array}{l}\text { Collar } \\
\text { Type }\end{array}$ & $\begin{array}{l}\text { Capture } \\
\text { Date }\end{array}$ & $\begin{array}{l}\text { Deer } \\
\text { ID }\end{array}$ & Frequency & $\begin{array}{l}\text { Collar } \\
\text { Type }\end{array}$ & $\begin{array}{l}\text { Capture } \\
\text { Date }\end{array}$ \\
\hline 1 & 150.101 & GPS & $2 / 9 / 2005$ & 33 & 149.221 & VHF & $2 / 9 / 2005$ \\
\hline 2 & 150.111 & GPS & $2 / 9 / 2005$ & 34 & 149.302 & VHF & $2 / 9 / 2005$ \\
\hline 3 & 150.121 & GPS & $2 / 9 / 2005$ & 35 & 149.333 & VHF & $2 / 9 / 2005$ \\
\hline 4 & 150.130 & GPS & $2 / 9 / 2005$ & 36 & 149.342 & VHF & $2 / 9 / 2005$ \\
\hline 5 & 150.140 & GPS & $2 / 9 / 2005$ & 37 & 149.371 & VHF & $2 / 9 / 2005$ \\
\hline 6 & 150.150 & GPS & $2 / 9 / 2005$ & 38 & 149.412 & VHF & $2 / 9 / 2005$ \\
\hline 7 & 150.161 & GPS & $2 / 9 / 2005$ & 39 & 149.442 & VHF & $2 / 9 / 2005$ \\
\hline 8 & 150.170 & GPS & $2 / 9 / 2005$ & 40 & 149.700 & VHF & $2 / 9 / 2005$ \\
\hline 9 & 150.180 & GPS & $2 / 9 / 2005$ & 41 & 149.762 & \begin{tabular}{|l|} 
VHF \\
\end{tabular} & $2 / 9 / 2005$ \\
\hline 10 & 150.190 & GPS & $2 / 9 / 2005$ & 42 & 148.392 & \begin{tabular}{|l|} 
VHF \\
\end{tabular} & $12 / 10 / 2005$ \\
\hline 11 & 150.200 & GPS & $2 / 9 / 2005$ & 43 & 148.413 & \begin{tabular}{|l} 
VHF \\
\end{tabular} & $12 / 10 / 2005$ \\
\hline 12 & 150.211 & GPS & $2 / 9 / 2005$ & 44 & 148.443 & VHF & $12 / 10 / 2005$ \\
\hline 13 & 150.221 & GPS & $2 / 9 / 2005$ & 45 & 148.772 & VHF & $12 / 10 / 2005$ \\
\hline 14 & \begin{tabular}{|l|}
150.230 \\
\end{tabular} & GPS & $2 / 9 / 2005$ & 46 & 150.101 & GPS & $12 / 10 / 2005$ \\
\hline 15 & 150.240 & GPS & $2 / 9 / 2005$ & 47 & 150.111 & GPS & $12 / 10 / 2005$ \\
\hline 16 & \begin{tabular}{|l|}
150.251 \\
\end{tabular} & GPS & $2 / 9 / 2005$ & 48 & 150.121 & GPS & $12 / 10 / 2005$ \\
\hline 17 & 150.261 & GPS & $2 / 9 / 2005$ & 49 & 150.130 & GPS & $12 / 10 / 2005$ \\
\hline 18 & \begin{tabular}{|l|}
150.271 \\
\end{tabular} & GPS & $2 / 9 / 2005$ & 50 & 150.140 & GPS & $12 / 10 / 2005$ \\
\hline 19 & 150.281 & GPS & $2 / 9 / 2005$ & 51 & 150.150 & GPS & $12 / 10 / 2005$ \\
\hline 20 & 150.290 & GPS & $2 / 9 / 2005$ & 52 & 150.161 & GPS & $12 / 10 / 2005$ \\
\hline 21 & 150.301 & GPS & $2 / 9 / 2005$ & 53 & 150.170 & GPS & $12 / 10 / 2005$ \\
\hline 22 & 150.310 & GPS & $2 / 9 / 2005$ & 54 & 150.180 & GPS & $12 / 10 / 2005$ \\
\hline 23 & 150.320 & GPS & $2 / 9 / 2005$ & 55 & 150.190 & GPS & $12 / 10 / 2005$ \\
\hline 24 & 150.331 & GPS & $2 / 9 / 2005$ & 56 & 150.200 & GPS & $12 / 10 / 2005$ \\
\hline 25 & 150.340 & GPS & $2 / 9 / 2005$ & 57 & 150.211 & GPS & $12 / 10 / 2005$ \\
\hline 26 & \begin{tabular}{|l|}
150.351 \\
\end{tabular} & GPS & $2 / 9 / 2005$ & 58 & 150.221 & GPS & $12 / 10 / 2005$ \\
\hline 27 & \begin{tabular}{|l|}
150.360 \\
\end{tabular} & GPS & $2 / 9 / 2005$ & 59 & 150.230 & GPS & $12 / 10 / 2005$ \\
\hline 28 & \begin{tabular}{|l|}
150.371 \\
\end{tabular} & GPS & $2 / 9 / 2005$ & 60 & 150.240 & GPS & $12 / 10 / 2005$ \\
\hline 29 & \begin{tabular}{|l|}
150.381 \\
\end{tabular} & GPS & $2 / 9 / 2005$ & 61 & 150.271 & GPS & $12 / 10 / 2005$ \\
\hline 30 & 150.390 & GPS & $2 / 9 / 2005$ & 62 & 150.331 & GPS & $12 / 10 / 2005$ \\
\hline 31 & 150.411 & GPS & $2 / 9 / 2005$ & 63 & 150.371 & \begin{tabular}{|l|} 
GPS \\
\end{tabular} & $12 / 10 / 2005$ \\
\hline 32 & 149.174 & VHF & $2 / 9 / 2005$ & & & & \\
\hline
\end{tabular}




\subsection{GPS Collars}

We recovered 47 of 49 GPS collars. Collars \#29 and \#50 could not be located. The remote-release mechanisms (Photo 3) and GPS collections functioned properly for the 47 collars we retrieved. We collected 116,494 GPS locations from 47 deer between 10 February 2005 and 15 November 2006 . Fix rate success $(99 \%)$ and accuracy $(85 \%$ of the locations were 3-dimensional) was high (i.e., $<20$ meter error; Di Orio et al. 2003).

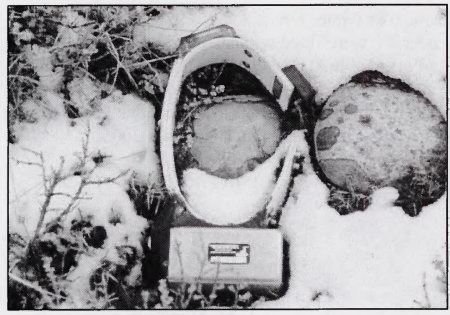

Photo 3. Released GPS-collar.

\subsection{Adult Survival and Mortality}

Twelve radiomarked deer died between February 2005 and 15 November 2006 (Table 2). Cause of death could not be determined for 7 of the 12. Estimated annual (01 June 2005-31 May 2006) survival was 0.80 ( $\mathrm{SE}=0.06$ ), with a $90 \%$ confidence interval of $0.73-0.87$. Winter (01 December 2005 - 30 April 2006) survival was not estimated because no deaths occurred during that time period.

Table 2. List of radiomarked deer that died between February 2005 and November 2006.

\begin{tabular}{|l|l|l|l|l|}
\hline ID & Frequency & $\begin{array}{l}\text { Estimated } \\
\text { Death }\end{array}$ & Location & Cause of Death \\
\hline 12 & 150.211 & $4-28-05$ & Sand Hills & Unknown: carcass present, deteriorated \\
\hline 10 & 150.190 & $7-20-05$ & Dexter Peak & Predation: cougar \\
\hline 1 & 150.101 & $9-21-05$ & Sand Hills & Unknown: carcass scavenged \\
\hline 28 & 150.371 & $10-1-05$ & Adams Reservoir & Unknown: carcass present, deteriorated \\
\hline 24 & 150.331 & $10-6-05$ & Spring Creek & Rifle harvest \\
\hline 7 & 150.161 & $10-24-05$ & Coal Gulch & Wounding loss \\
\hline 18 & 150.271 & $11-11-05$ & Sand Hills & Unknown: carcass present, scavenged \\
\hline 21 & 150.301 & $5-08-06$ & Upper Muddy Creek & No carcass found, only collar \\
\hline 56 & 150.200 & $5-08-06$ & Coal Gulch & Unknown: old carcass \\
\hline 48 & 150.121 & $5-23-06$ & South McCarty Canyon & Likely predation: carcass scavenged \\
\hline 25 & 150.340 & $11-13-06$ & Wild Horse Basin & Natural causes, fresh carcass \\
\hline 17 & 150.261 & $11-15-06$ & Muddy Creek Canyon & Unknown: carcass in ice \\
\hline
\end{tabular}




\subsection{GPS Collars}

We recovered 47 of 49 GPS collars. Collars \#29 and \#50 could not be located. The remote-release mechanisms (Photo 3) and GPS collections functioned properly for the 47 collars we retrieved. We collected 116,494 GPS locations from 47 deer between 10 February 2005 and 15 November 2006. Fix rate success $(99 \%)$ and accuracy $(85 \%$ of the locations were 3-dimensional) was high (i.e., $<20$ meter error; Di Orio et al. 2003).

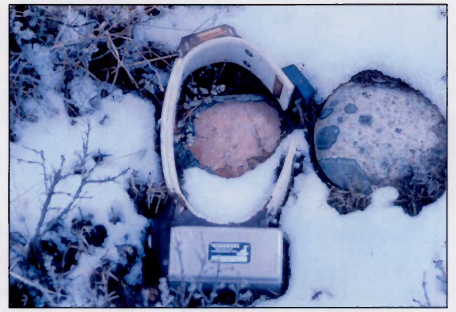

Photo 3. Released GPS-collar.

\subsection{Adult Survival and Mortality}

Twelve radiomarked deer died between February 2005 and 15 November 2006 (Table 2). Cause of death could not be determined for 7 of the 12. Estimated annual ( 01 June $2005-31$ May 2006) survival was $0.80(\mathrm{SE}=0.06)$, with a $90 \%$ confidence interval of $0.73-0.87$. Winter (01 December 2005 - 30 April 2006) survival was not estimated because no deaths occurred during that time period.

Table 2. List of radiomarked deer that died between February 2005 and November 2006.

\begin{tabular}{|l|l|l|l|l|}
\hline ID & Frequency & $\begin{array}{l}\text { Estimated } \\
\text { Death }\end{array}$ & Location & Cause of Death \\
\hline 12 & 150.211 & $4-28-05$ & Sand Hills & Unknown: carcass present, deteriorated \\
\hline 10 & 150.190 & $7-20-05$ & Dexter Peak & Predation: cougar \\
\hline 1 & 150.101 & $9-21-05$ & Sand Hills & Unknown: carcass scavenged \\
\hline 28 & 150.371 & $10-1-05$ & Adams Reservoir & Unknown: carcass present, deteriorated \\
\hline 24 & 150.331 & $10-6-05$ & Spring Creek & Rifle harvest \\
\hline 7 & 150.161 & $10-24-05$ & Coal Gulch & Wounding loss \\
\hline 18 & 150.271 & $11-11-05$ & Sand Hills & Unknown: carcass present, scavenged \\
\hline 21 & 150.301 & $5-08-06$ & Upper Muddy Creek & No carcass found, only collar \\
\hline 56 & 150.200 & $5-08-06$ & Coal Gulch & Unknown: old carcass \\
\hline 48 & 150.121 & $5-23-06$ & South McCarty Canyon & Likely predation: carcass scavenged \\
\hline 25 & 150.340 & $11-13-06$ & Wild Horse Basin & Natural causes, fresh carcass \\
\hline 17 & 150.261 & $11-15-06$ & Muddy Creek Canyon & Unknown: carcass in ice \\
\hline
\end{tabular}





\subsection{Seasonal Distribution, Migration, and Movement Rates}

To help visualize and interpret the 116,494 GPS locations, we generated specific maps for winter (December 1 - March 30; Figure 3), summer (June 1 - September 30; Figure 4), transition (April 15 - May 15 and October 1 - November 15; Figure 5), and parturition (June 1-14; Figure 6) periods. Mule deer spent all or part of the winter in three winter ranges, the Dad-Juniper, Wild Horse, and Sand Hills winter ranges. Most mule deer in the ARPA wintered in either on the Dad-Juniper Winter Range or the Wild Horse Winter Range (Figure 3). The Dad-Juniper Winter Range encompassed approximately $25 \mathrm{mi}^{2}$ in the west-central portion of the ARPA and extended northerly from Dad to Doty Mountain along a sagebrush juniper ridge immediately southeast of Muddy Creek. The Wild Horse Winter Range encompassed approximately $70 \mathrm{mi}^{2}$ in the southwest portion of the ARPA. This range began near the confluence Wild Cow and Muddy Creek, and extended south approximately 10 miles across Cherokee Creek, Wild Horse Draw, and Muddy Mountain. Mule deer from both the Dad-Juniper and Wild Horse winter ranges also utilized the Sand Hills Winter Range (Figure 3) during early winter (November, December and early-January). The Sand Hills Winter Range generally refers to $20-25 \mathrm{mi}^{2}$ along the west-facing slopes between Muddy Creek Canyon and Cow Creek, however additional winter and transition range occurred from Cow Creek to Deep Creek and Wild Cow Creek.

Of the 45,945 GPS locations collected during the winter (December 1 - March 30), $93 \%(n=42,851)$ occurred in areas designated as Crucial Winter - Yearlong Range by the WGFD (Figure 3). However, there were isolated clusters of winter locations $(n=3,094)$ that occurred outside designated winter ranges, including: 1) the area immediately east of Deep Creek Rim along a portion of Deep Creek and 2) the base of Deep Gulch along Cow Creek and south to Wild Cow Creek (Figure 3).

Of the 47 GPS-marked deer, 46 were considered migratory and utilized distinct seasonal ranges (Table 3 ). The average migration distance between winter and summer ranges was 26.5 miles $(n=46, S E=1.35)$ and ranged from 5 to 48 miles (Table 3 ). Spring migrations usually occurred in early-April through mid-May, while fall migrations occurred October through December (Table 3). All summer ranges occurred east or northeast of winter ranges and approximately $87 \%(n=40)$ of GPS-collared deer occupied summer ranges outside of the ARPA (Table 3; Figure 4). GPS-collared deer congregated on transition ranges during the spring and fall periods (Figure 5). The east-central portion of the project area, generally from Muddy Creek Canyon and the Sand Hills south to Wild Cow Creek, provided important transition ranges for a large segment of the mule deer population and year-around range for a smaller segment (Figures 5 and 6).

Straight-line distances between GPS locations were useful for illustrating movement patterns across the ARPA (Figure 7). However, to specifically delineate migration routes, rather than day to day non-migratory movements, we identified movement paths where deer were moving at least $0.40 \mathrm{mi} / \mathrm{hr}$ (Figure 8 ). We assumed the high-velocity movement paths in Figure 8 represented spring and fall migration routes and generally excluded the lowervelocity movements of summer and winter ranges. These high-velocity movement paths were then used to digitize common migration routes in areas where multiple high-velocity movement paths occurred (Figure 9). We applied a 0.25 -mi buffer on the common migration routes (Figure 10) such that most high-velocity movement paths were contained within the buffered regions. We recognize that the width of migration routes may vary across the 
landscape and that the 0.25 buffer may be too large in some areas and too small in others. But, until a more quantitative technique is available (e.g., Horne et al. 2007), assigning a buffer width that encompasses most high-velocity movement paths can be used to illustrate and identify the approximate area of common migration routes. Migration routes were often welldefined and consistently used by multiple animals across both spring and fall migrations. For example, deer wintering in the Dad area migrated along the Muddy Creek corridor to Muddy Creek Canyon (Figure 11) before moving to summer ranges on Atlantic Rim or Miller Hill. And, deer wintering in the Wild Horse/Muddy Mountain area consistently used migration routes through the Brown Cow POD and north to transition ranges in the Sandhills and/or the Wild Cow/Deep Gulch areas (Figure 12).

Average daily movement rates for GPS-collared deer ranged from 0.6 miles/day in June of 2005 to 4.6 miles/day in December of 2005 (Figure 13). The average daily movement rate during the winter months was 1.25 miles/day. Movement rates were not calculated for the summer period (June 15 - September 30) because GPS locations were collected only once per day. During spring and fall migrations, daily movement rates increased to $1.5-3.0 \mathrm{miles} /$ day and occasionally increased to 3.5 or 4.0 miles/day. Daily movement rates were also elevated ( 1.5 $-2.25 \mathrm{miles} /$ day) during the rifle hunting season. Fall migration to transition ranges and elevated movement rates corresponded with the rifle hunting season in early October. This was followed by a period of lower daily movement before deer continued on to their respective winter ranges. Plots of daily movement rates (Figure 13) appeared to be a useful tool for identifying the timing of spring and fall migrations.

Deer distribution in relation to proposed POD locations varied from north to south (Figure 14). No GPS-collared deer locations occurred in many of the northern PODs, including Red Rim, Jolly Roger Alpha, Jolly Roger Beta, Sun Dog, and Blue Sky. The Doty Mountain and Cow Creek PODs received limited use. The extreme northern and southern edges of the Doty Mountain POD were used as mule deer migration routes, and a small portion ( $~ 80$ acres) along the western edge of the Cow Creek POD was used as mule deer winter range. However, the two southern PODs, Brown Cow and Muddy Mountain, received substantial amounts of both winter and transition use by GPS-collared deer. Additionally, most GPS-collared deer migrated through portions of the Brown Cow or Muddy Mountain PODs to reach their respective summer ranges.

Relative to WGFD hunt areas (HA), 75\% $(n=35)$ of GPS-collared deer spent the majority of the winter in HA 82 (Table 3; Figure 14), occasionally crossing WY 789 and moving into HA 100 near Fivemile Point. The other $25 \%(n=12)$ spent the majority of winter in HA 100. During the summer $91 \%(n=43)$ of GPS-collared deer occupied ranges in HA 84 $(n=18)$ and HA $82(n=25)$, while $9 \%(n=4)$ deer $(\# 24)$ summered in HA 80 (Table 3).

We organized all 116,494 GPS locations into a GIS database (ArcView shapefile with metadata) that study cooperators can easily access and map with ArcView software. The database includes the date, time, satellite precision, latitude, longitude, UTM coordinates, animal ID, herd unit, hunt area, seasonal range, and land ownership for each GPS location. 
Table 3. Summary of radiomarked deer distribution and migration.

\begin{tabular}{|c|c|c|c|c|c|c|c|c|}
\hline \multirow[b]{2}{*}{ ID } & \multirow{2}{*}{$\begin{array}{l}\text { Winter } \\
\text { Hunt } \\
\text { Area }\end{array}$} & \multirow{2}{*}{$\begin{array}{c}\text { Summer } \\
\text { Hunt } \\
\text { Area }\end{array}$} & \multirow{2}{*}{$\begin{array}{l}\text { Summer } \\
\text { IN or OUT } \\
\text { of ARPA }\end{array}$} & \multirow{2}{*}{$\begin{array}{l}\text { Migration } \\
\text { Distance } \\
\text { (mi) }\end{array}$} & \multicolumn{4}{|c|}{ Timing of Migrations } \\
\hline & & & & & Spring 05 & Fall 05 & Spring 06 & Fall 06 \\
\hline 1 & 100 & 82 & IN & 21.1 & April & $>$ Nov. 15 & $\mathrm{n} / \mathrm{a}$ & $\mathrm{n} / \mathrm{a}$ \\
\hline 2 & 82 & 84 & OUT & 22.0 & May & October & $\mathrm{n} / \mathrm{a}$ & $\mathrm{n} / \mathrm{a}$ \\
\hline 3 & 82 & 82 & $\mathrm{IN}$ & 14.8 & April & $>$ Nov. 15 & $\mathrm{n} / \mathrm{a}$ & $\mathrm{n} / \mathrm{a}$ \\
\hline 4 & 82 & 84 & OUT & 21.2 & April-May & Oct-Dec & $\mathrm{n} / \mathrm{a}$ & $\mathrm{n} / \mathrm{a}$ \\
\hline 5 & 82 & 84 & OUT & 29.8 & April & $>$ Nov. 15 & $\mathrm{n} / \mathrm{a}$ & $\mathrm{n} / \mathrm{a}$ \\
\hline 6 & 82 & 84 & OUT & 35.1 & April-May & Oct-Dec & $\mathrm{n} / \mathrm{a}$ & $\mathrm{n} / \mathrm{a}$ \\
\hline 7 & 82 & 82 & OUT & 16.1 & April & $>$ Nov. 15 & $\mathrm{n} / \mathrm{a}$ & $\mathrm{n} / \mathrm{a}$ \\
\hline 8 & 82 & 82 & OUT & 32.4 & April-May & Oct-Dec & $\mathrm{n} / \mathrm{a}$ & $\mathrm{n} / \mathrm{a}$ \\
\hline 9 & 82 & 84 & OUT & 29.9 & April & Oct-Dec & $\mathrm{n} / \mathrm{a}$ & $\mathrm{n} / \mathrm{a}$ \\
\hline 10 & 82 & 82 & OUT & 31.0 & April-May & $\mathrm{n} / \mathrm{a}$ & $\mathrm{n} / \mathrm{a}$ & $\mathrm{n} / \mathrm{a}$ \\
\hline 11 & 82 & 82 & OUT & 31.4 & April-May & Oct-Dec & $\mathrm{n} / \mathrm{a}$ & $\mathrm{n} / \mathrm{a}$ \\
\hline 12 & 82 & 82 & OUT & 27.8 & April & $\mathrm{n} / \mathrm{a}$ & $\mathrm{n} / \mathrm{a}$ & $\mathrm{n} / \mathrm{a}$ \\
\hline 13 & 82 & 82 & IN & 5.0 & SDM & SDM & $\mathrm{n} / \mathrm{a}$ & $\mathrm{n} / \mathrm{a}$ \\
\hline 14 & 82 & 82 & OUT & 15.4 & April & October & $\mathrm{n} / \mathrm{a}$ & $\mathrm{n} / \mathrm{a}$ \\
\hline 15 & 100 & 82 & OUT & 26.4 & April & $>$ Nov. 15 & $\mathrm{n} / \mathrm{a}$ & $\mathrm{n} / \mathrm{a}$ \\
\hline 16 & 82 & 82 & OUT & 17.9 & April & December & April & $\mathrm{n} / \mathrm{a}$ \\
\hline 17 & 82 & 84 & OUT & 26.2 & April & November & April & November \\
\hline 18 & 82 & 84 & OUT & 31.3 & April-May & Oct-Dec & $\mathrm{n} / \mathrm{a}$ & $\mathrm{n} / \mathrm{a}$ \\
\hline 19 & 82 & 84 & OUT & 27.6 & April-May & Oct-Dec & April & Oct-Nov \\
\hline 20 & 100 & 82 & IN & 17.6 & April & January & April & November \\
\hline 21 & 100 & 80 & OUT & 47.1 & April-May & Oct-Dec & April-May & $\mathrm{n} / \mathrm{a}$ \\
\hline 22 & 82 & 82 & OUT & 20.1 & April & December & April & $>$ Nov. 15 \\
\hline 23 & 82 & 82 & OUT & 36.6 & April-May & Oct-Dec & April-May & Oct-Nov \\
\hline 24 & 82 & 80 & OUT & 47.9 & April-May & $\mathrm{n} / \mathrm{a}$ & $\mathrm{n} / \mathrm{a}$ & $\mathrm{n} / \mathrm{a}$ \\
\hline 25 & 82 & 82 & OUT & 22.2 & April-May & October & April-May & October \\
\hline 26 & 82 & 82 & OUT & 36.0 & April-May & Oct-Dec & April-May & Oct-Nov \\
\hline 27 & 82 & 82 & $\mathrm{IN}$ & 13.2 & April & December & April & $>$ Nov. 15 \\
\hline 28 & 82 & 84 & OUT & 40.5 & April-May & $\mathrm{n} / \mathrm{a}$ & $\mathrm{n} / \mathrm{a}$ & $\mathrm{n} / \mathrm{a}$ \\
\hline 30 & 100 & 82 & OUT & 26.2 & April & October & April & October \\
\hline 31 & 100 & 80 & OUT & 43.5 & April-May & Oct-Dec & April-May & October \\
\hline 46 & 82 & 84 & OUT & 22.7 & $\mathrm{n} / \mathrm{a}$ & December & April-May & Oct-Nov \\
\hline 47 & 82 & 82 & $\mathrm{IN}$ & RESIDENT & $\mathrm{n} / \mathrm{a}$ & $\mathrm{n} / \mathrm{a}$ & $\mathrm{n} / \mathrm{a}$ & $\mathrm{n} / \mathrm{a}$ \\
\hline 48 & 82 & 82 & OUT & 21.7 & April & $\mathrm{n} / \mathrm{a}$ & $\mathrm{n} / \mathrm{a}$ & $\mathrm{n} / \mathrm{a}$ \\
\hline 49 & 100 & 82 & OUT & 24.9 & $\mathrm{n} / \mathrm{a}$ & $\mathrm{n} / \mathrm{a}$ & April & October \\
\hline 51 & 100 & 84 & OUT & 35.8 & $\mathrm{n} / \mathrm{a}$ & December & April-May & Oct-Nov \\
\hline 52 & 82 & 84 & OUT & 22.9 & $\mathrm{n} / \mathrm{a}$ & $\mathrm{n} / \mathrm{a}$ & April & October \\
\hline 53 & 82 & 84 & OUT & 26.5 & $\mathrm{n} / \mathrm{a}$ & $\mathrm{n} / \mathrm{a}$ & April & October \\
\hline 54 & 82 & 82 & OUT & 27.9 & $\mathrm{n} / \mathrm{a}$ & December & April & $>$ Nov. 15 \\
\hline 55 & 100 & 82 & IN & 35.8 & $\mathrm{n} / \mathrm{a}$ & $\mathrm{n} / \mathrm{a}$ & April & $>$ Nov. 15 \\
\hline 56 & 100 & 82 & OUT & 19.1 & $\mathrm{n} / \mathrm{a}$ & $\mathrm{n} / \mathrm{a}$ & April & $\mathrm{n} / \mathrm{a}$ \\
\hline 57 & 82 & 84 & OUT & 16.7 & $\mathrm{n} / \mathrm{a}$ & $\mathrm{n} / \mathrm{a}$ & April & $>$ Nov. 15 \\
\hline 58 & 82 & 84 & OUT & 18.6 & $\mathrm{n} / \mathrm{a}$ & December & April & Oct-Nov \\
\hline 59 & 82 & 84 & OUT & 15.3 & $\mathrm{n} / \mathrm{a}$ & December & April & Oct-Nov \\
\hline 60 & 82 & 84 & OUT & 27.8 & $\mathrm{n} / \mathrm{a}$ & $\mathrm{n} / \mathrm{a}$ & April & Oct-Nov \\
\hline 61 & 82 & 80 & OUT & 36.4 & $\mathrm{n} / \mathrm{a}$ & $\mathrm{n} / \mathrm{a}$ & April-May & October \\
\hline 62 & 100 & 84 & OUT & 31.9 & $\mathrm{n} / \mathrm{a}$ & $\mathrm{n} / \mathrm{a}$ & April & October \\
\hline 63 & 100 & 82 & OUT & 24.7 & $\mathrm{n} / \mathrm{a}$ & $\mathrm{n} / \mathrm{a}$ & April & October \\
\hline
\end{tabular}





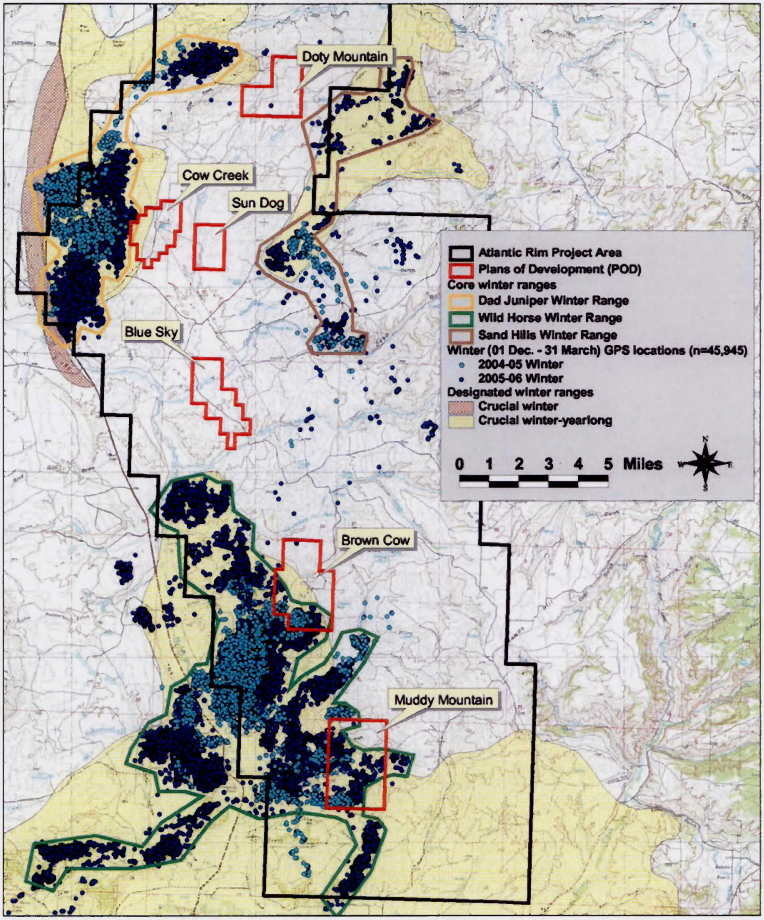

Figure 3. Winter locations $(n=45,945)$ of 47 GPS-marked deer in the Atlantic Rim Project Area (ARPA), February 10 - March 31, 2005 and December 1-March 31, 2006. 


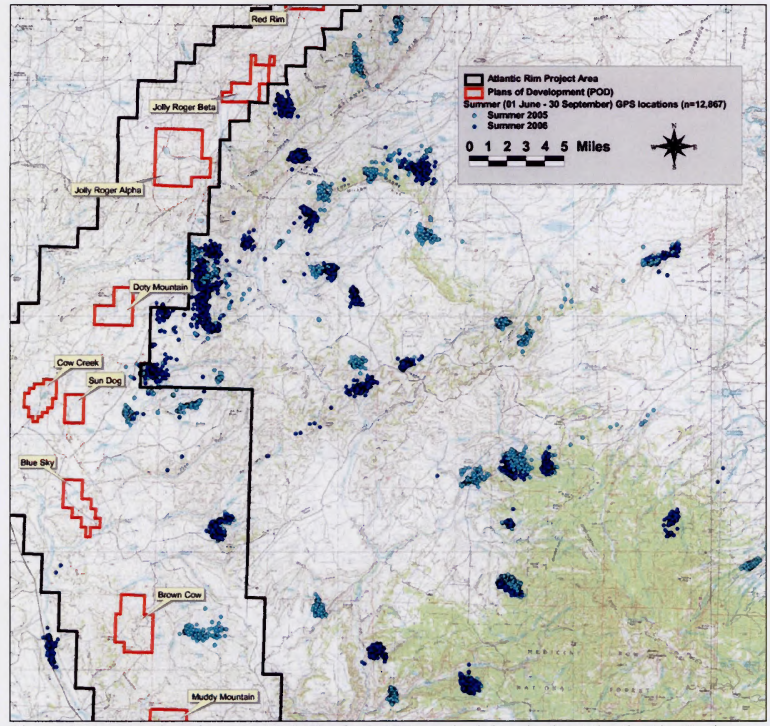

Figure 4. Summer locations ( $n=12,567)$ of 45 GPS-marked deer in the Atlantic Rim Project Area (ARPA), June 1 through September 20, 2005 - 2006. 



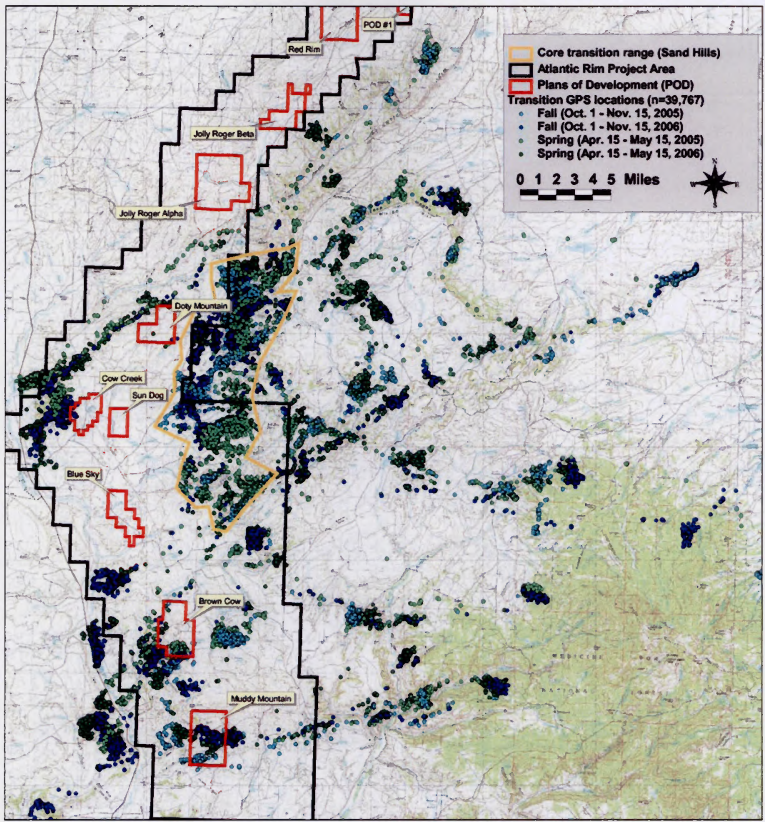

Figure 5. Transition locations $(n=39,767)$ of 47 GPS-marked deer in the Atlantic Rim Project Area (ARPA) during the spring (April 15-May 15) and fall (October 1 -November 15) of 2005 and 2006. 



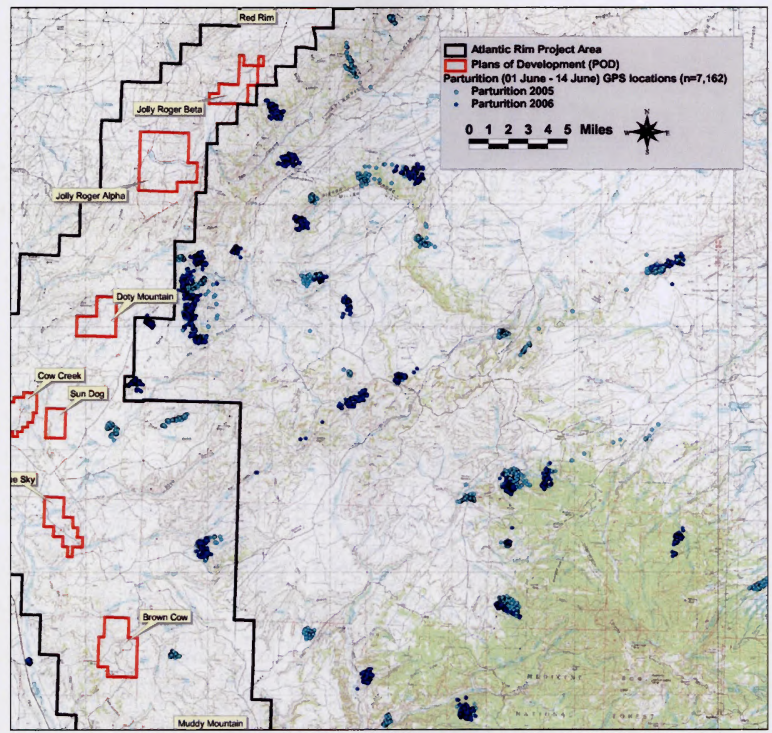

Figure 6. Parturition locations $(n=7,162)$ of 45 GPS-marked deer in the Atlantic Rim Project Area (ARPA), June $1-14,2005-2006$. 



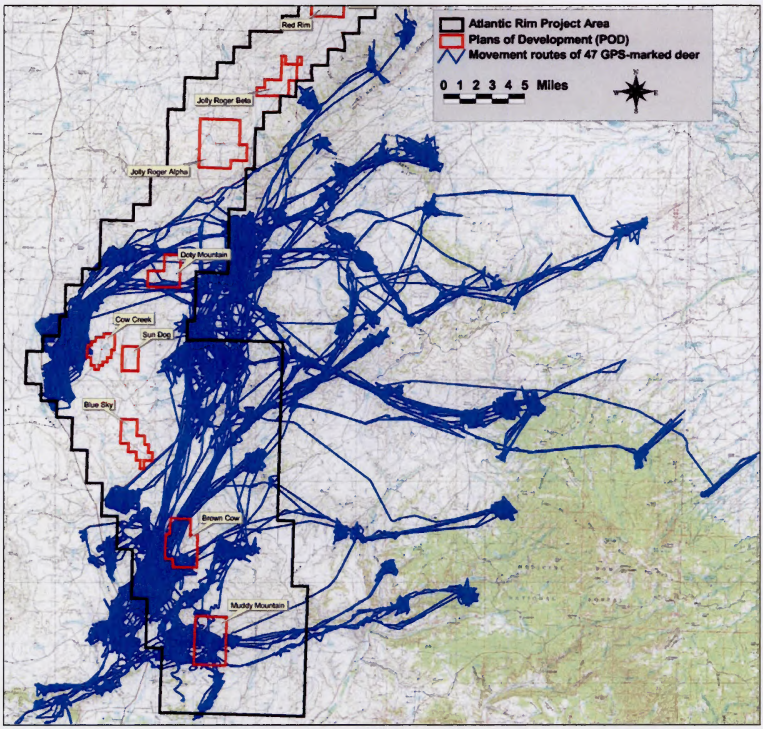

Figure 7. Movement routes collected from of 47 GPS-collared mule deer between February 10, 2005 and November 15, 2006 in the Atlantic Rim Project Area (ARPA). 



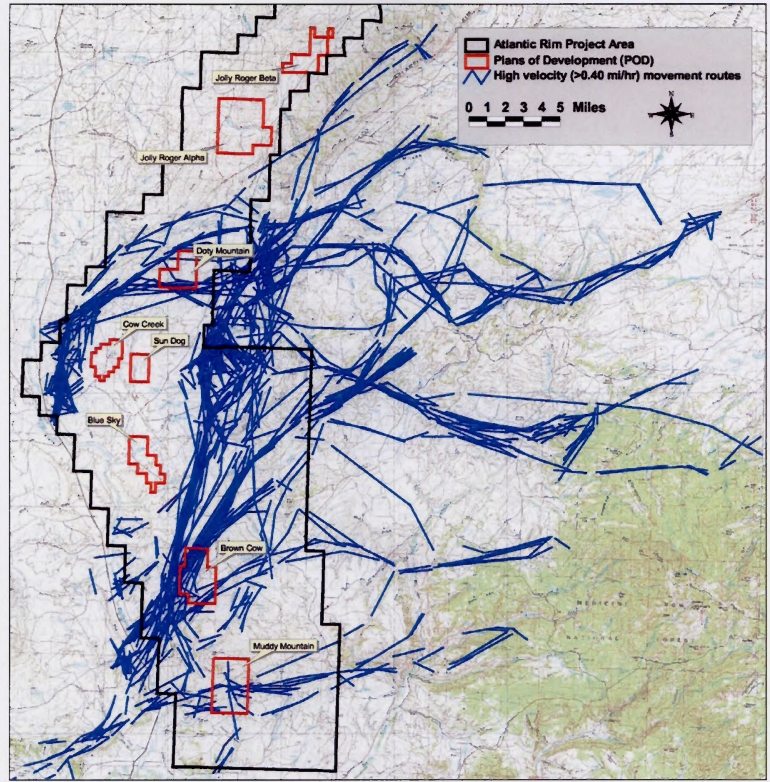

Figure 8 . High-velocity $(0.40 \mathrm{mi} / \mathrm{hr})$ movement routes collected from of $47 \mathrm{GPS}$-collared mule deer between February 10, 2005 and November 15, 2006 in the Atlantic Rim Project Area (ARPA). 



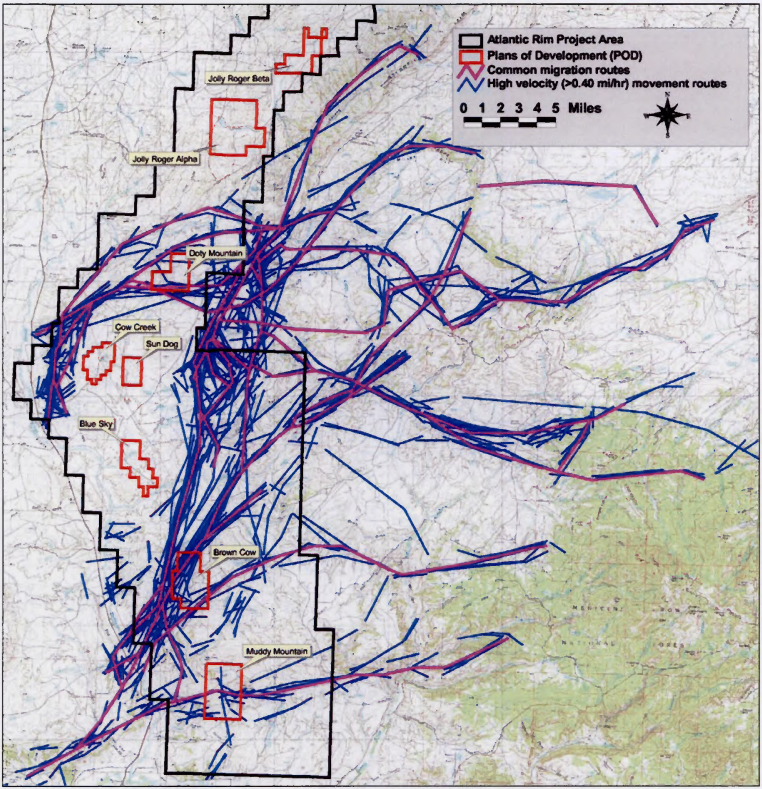

Figure 9. Common migration routes digitized from the high-velocity movement routes of 47 GPS-collared mule deer, February 10, 2005 - November 15, 2006 in the Atlantic Rim Project Area (ARPA). 



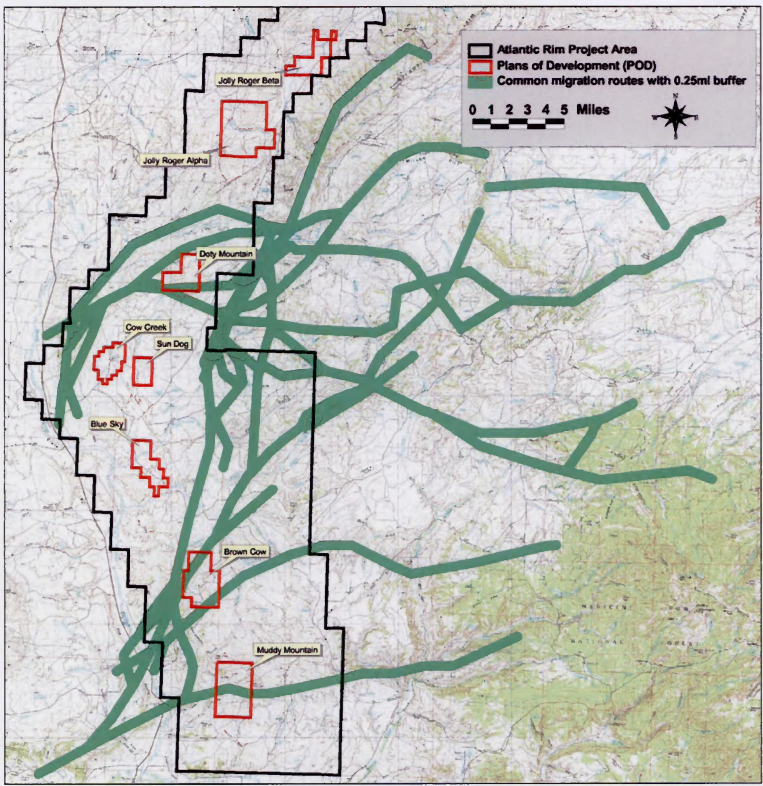

Figure 10. Common migration routes with $0.25 \mathrm{mi}$ buffer estimated from of 47 GPS-collared mule deer between February 10, 2005 and November 15, 2006 in the Atlantic Rim Project Area (ARPA). 



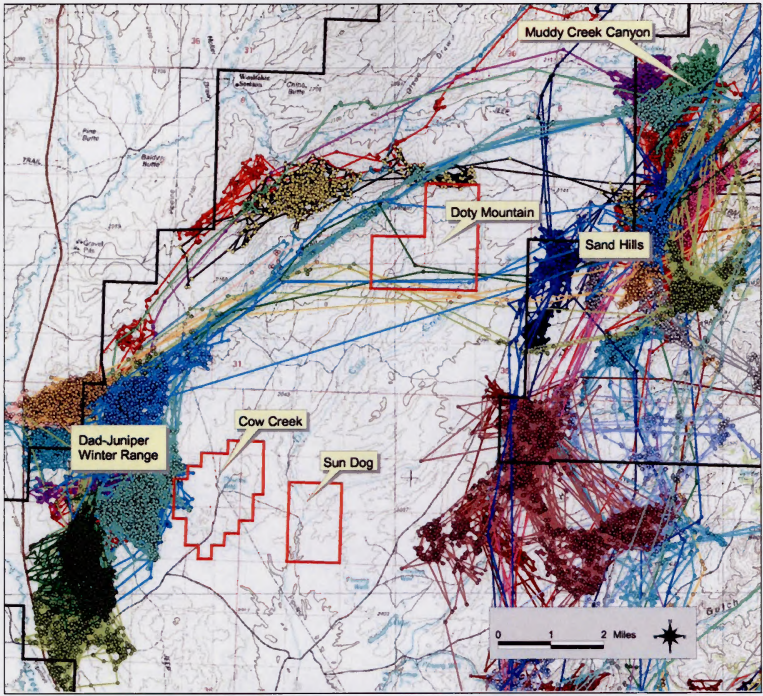

Figure 11. Migration routes of GPS-collared deer to and from the Dad-Juniper Winter Range, along the Muddy Creek corridor to Muddy Creek Canyon and the Sand Hills, February 10, 2005 - November 15, 2006 in the Atlantic Rim Project Area (ARPA). 



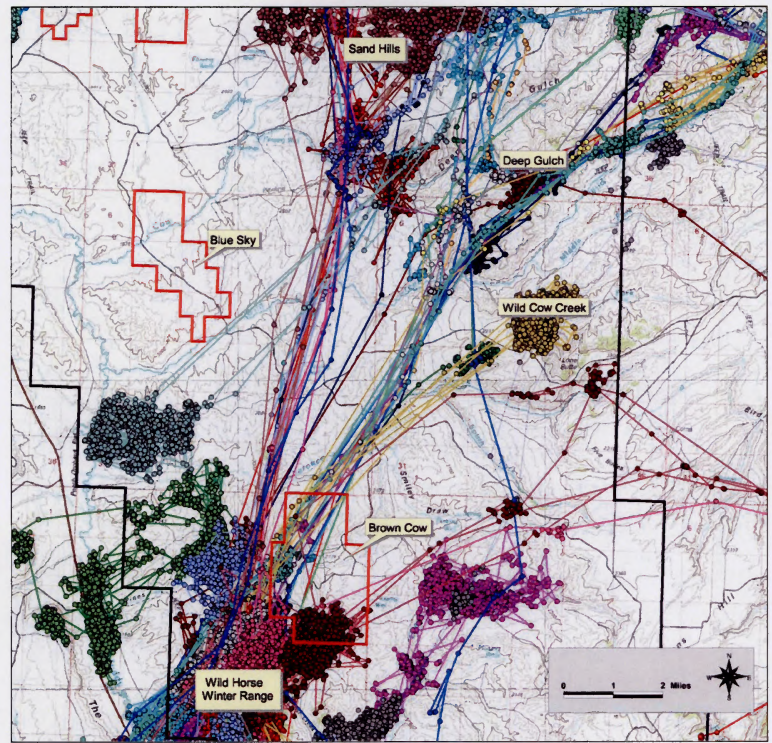

Figure 12. Migration routes of GPS-collared deer to and from the Wild Horse Winter Range and their proximity to the Brown Cow POD, February 10, 2005-November 15, 2006 in the Atlantic Rim Project Area (ARPA). 



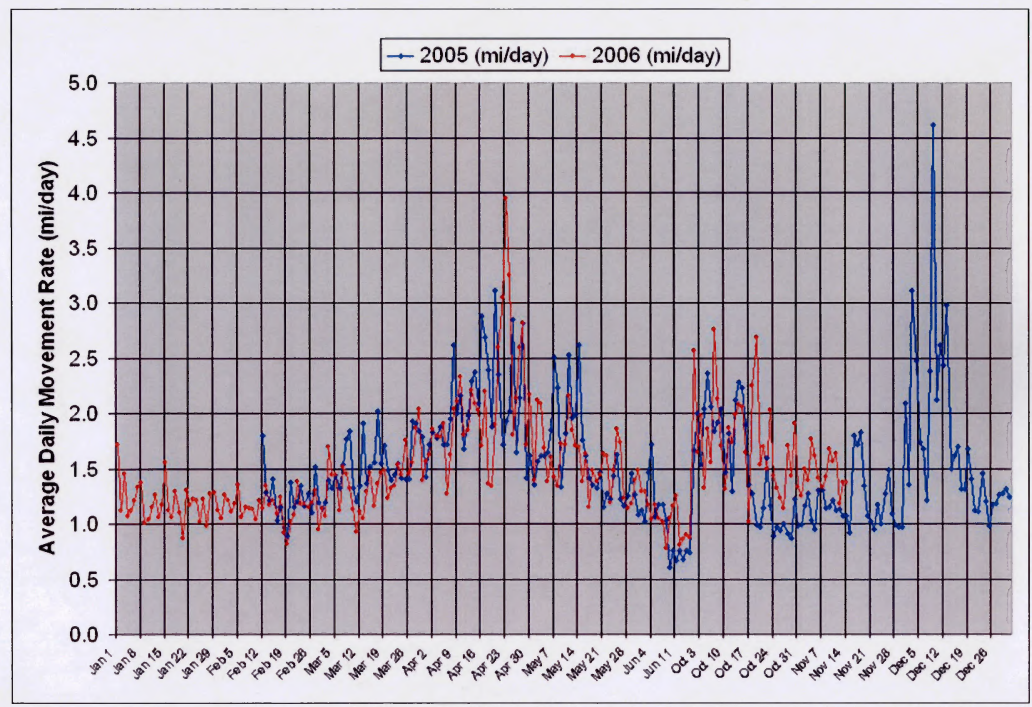

Figure 13. Average daily movement rates (miles/day) of 47 GPS-collared mule deer in the Atlantic Rim Project Area, February 5 June 15, 2005, October 1, 2005 - June 15, 2006, and October 1, 2006 - November 15, 2006. 



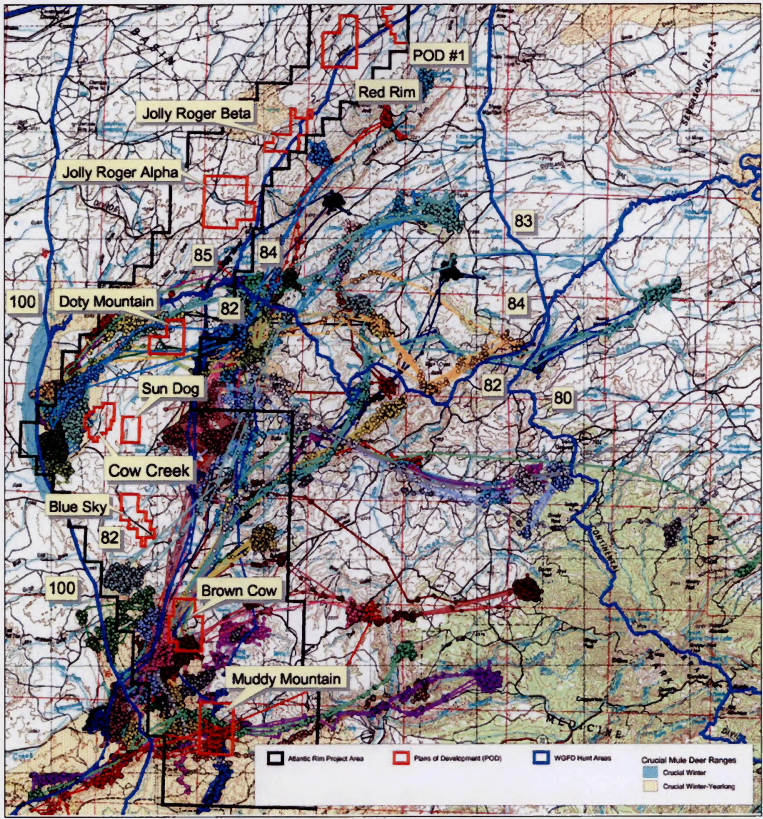

Figure 14. Locations and movement routes of 47-GPS collared deer relative to crucial mule deer winter ranges, mule deer hunt areas, and plans of development (POD) in the Atlantic Rim Project Area (ARPA) in south-central Wyoming, February 10, 2005 - November 15, 2006. 



\subsection{DISCUSSION}

Since the 1980's the Baggs Herd Unit (BHU) has supported one of Wyoming's largest deer herds and provided exceptional recreational opportunities to both resident and nonresident sportsmen. Mule deer hunting in the BHU is known for plentiful deer numbers, an abundance of public land, above-average success rates, and liberal license allocations. Mule deer hunting in the BHU consistently provides more than 14,000 recreation days each year (Woolley 2005). Despite long-term drought conditions, range degradation (Nelson et al. 1994), and relatively low recruitment rates ( $<60$ fawns per 100 does), the BHU 5-year population average of 21,480 has remained well above the WGFD objective of 18,700 animals (Woolley 2005). The number of mature bucks has declined in recent years, but the overall BHU mule deer population appears to be stable (Woolley 2005). However, the estimated annual survival rates of female mule deer observed during this study $(\hat{S}=0.80)$ were slightly lower than those reported in Colorado ( $\hat{S}=0.83$; White et al. 1996), Idaho, and Montana $\hat{S}=(0.85$; Unsworth et al. 1999). Sustaining the BHU population at objective levels is a top priority for the WGFD and will require that functional seasonal ranges and migration routes be maintained. Our study provides the baseline data necessary to accurately identify seasonal ranges and migration routes, both of which will be key components for successful mule deer management and mitigation as energy resources are developed in the ARPA.

Our data collection was limited to adult females because they represent the reproductive segment and are therefore considered the most biologically important component of the population. Spatial segregation of the sexes occurs in a variety of ungulates outside of the breeding season, including mule deer (King and Smith 1980, Bowyer 1984, Main and Coblentz 1996), so we recognize that the habitat selection patterns of adult males may differ from females and young. However, because the spatial segregation of the sexes occurs at a relatively fine scale (Bowyer et al. 1996), we assume that inference(s) made from GPScollared females to the entire mule deer population is appropriate for assessing seasonal ranges and migration routes in the ARPA. Additionally, our data only reflect the movement and distribution patterns of mule deer that winter in the ARPA. However, we recognize that migratory mule deer from regions outside the ARPA (e.g., Little Snake River, Savery, Powder Wash, Poison Basin) migrate through or occupy portions of the ARPA during spring, summer, and fall periods (Nelson et al. 1994, Porter 1999).

Our data suggest that mule deer rely on several important seasonal ranges in the ARPA, including winter ranges located in the west-central (Dad Juniper Winter Range) and southwest (Wild Horse Winter Range) portions of the study area, and a transition range situated around the Sand Hills in the east-central portion of the ARPA. The importance of the Sand Hills transition range is highlighted by the fact that mule deer from both winter ranges utilized the area during both fall and spring migrations, and often for parturition. Additionally, Porter (1999) reported that the Wild Horse Winter Range and Sand Hills were also important transition areas for mule deer migrating to and from the Powder Rim Winter Range located approximately 30 miles west of Baggs. Transition ranges generally provide mule deer with better foraging opportunities than those available on winter ranges, allowing them to recover body condition earlier in the spring and maintain body condition later in the fall, before entering winter (Short 1981). Effective transition ranges alleviate foraging pressure on winter ranges and minimize the amount of time deer must spend on winter range (Short 1981). Managers should not overlook the importance of all seasonal ranges for maintaining healthy 
and productive mule deer populations (Short 1981, Clements and Young 1997). Summer, transition, and winter ranges are equally important components of mule deer ranges in Wyoming and, while the relative importance of each may change annually, the loss or degradation of one will not be compensated for by the others (Sawyer et al. 2005).

The potential impacts of gas development in the ARPA (BLM 2006) include direct habitat losses that occur when native vegetation is converted to infrastructure, and indirect habitat losses that occur if mule deer are displaced or avoid areas near infrastructure. Indirect habitat losses can be substantially larger than direct habitat losses. For example, following 3 years of gas development in western Wyoming, $41 \%$ of areas classified as high deer use prior to development changed to medium-low or low-use areas (Sawyer et al. 2006a). This change in distribution occurred with only $2 \%$ direct habitat loss (Sawyer et al. 2006b). Indirect habitat losses can likely be minimized by reducing the amount of human activity (i.e., traffic). However, this may require approaches or mitigation measures that limit the level of human activity during both production (e.g., fluid collection systems) and development phases of wells. Relatively small amounts of direct habitat loss can affect winter distribution patterns of mule deer (Sawyer et al. 2006a) and the effects of direct habitat loss may be long term for species like mule deer that rely on native shrubs (i.e., sagebrush) because reclamation of native shrubs in arid environments is difficult and has rarely been accomplished in southwest Wyoming.

Mule deer preference for sagebrush species as winter forage is well-documented (Sheehy and Winward 1981, Wambolt 2001) and their use of sagebrush in the BHU winter ranges is no exception. Nelson et al. (1994) found approximately $74 \%$ of winter mule deer diets in the BHU consisted of Wyoming big sagebrush, and Debolt (2000) found Wyoming big sagebrush made up $>70 \%$ of diets on winter ranges west of WY789. Because of the importance of sagebrush to mule deer, the winter and transition ranges identified in the ARPA may be used as target areas for specific management prescriptions (e.g., habitat improvements), mitigation (e.g., minimize direct loss of native shrubs), or reclamation practices (e.g., shrub establishment) intended to benefit mule deer. It is worth noting that winter conditions during this study were considered mild to average, and the deer distributions we observed reflect those conditions. Because most winters (e.g., 8 or 9 out of 10 years) are not considered severe, distribution patterns documented in this study should apply during most years. However, during more severe winters we would expect mule deer distribution patterns to shift to lower elevations and south-facing slopes. Nelson et al. (1994) and other observational WGFD data (T. Woolley, Wyoming Game and Fish Department, unpublished data) suggest that many mule deer from the ARPA migrate further west into the Poison Basin area during harsh winters. During the severe winter of 1983, mule deer numbers increased more than $300 \%$ in Poison Basin (Nelson et al. 1994).

Migrations between summer and winter ranges generally follow traditional routes that are learned and passed on from mother to young (McCullough 1985). Without migratory routes, many of the seasonal ranges in the BHU would be inaccessible to mule deer, and it is unlikely current populations could be maintained. Given that $98 \%$ of GPS-collared deer in the ARPA were migratory, identifying and conserving migration routes to and from seasonal ranges will be a key component to successful mule deer management in the BHU. The GPS data collected in this study accurately identified the location of migration routes across the ARPA, prior to gas development proposed in BLM (2006). Until recently, conserving migration routes has not been a top management concern for agencies because there have 
been no large-scale habitat alterations in the ARPA or BHU and the landscape has remained relatively unchanged. However, the recent BLM approval to develop 2,000 gas wells at a spacing of 8 per section and improve or construct approximately 1,000 miles of road and pipeline (BLM 2006) will result in large-scale habitat changes that could potentially impact the effectiveness of migration routes. While disturbances associated with gas development may alter habitat selection and distribution patterns of wintering mule deer (Sawyer et al. $2006 a$ ), it is unclear how or if gas development affects migration routes and migratory behavior. Nonetheless, accurately delineating migration routes prior to gas development in the ARPA provide the necessary tools to develop proactive measures to protect routes or minimize impacts to routes and/or study the potential effects of proposed development on routes.

The GPS data collected in this study also provided accurate information on the timing of migrations. Similar to Porter (1999), spring migrations occurred in April and May, with most movement taking place mid-April through early-May. Fall migrations were variable, but occurred from October through December, with most movement occurring in November and early-December. Timing of fall migrations was consistent with Porter (1999) who reported most deer returned to winter ranges west of WY789 between October 11 and December 15. Calculating average daily movement rates of GPS-collared deer was useful for identifying migratory time periods and suggests that migrations generally occur when movement rates exceed 1.5 miles/day.

\subsection{MANAGEMENT IMPLICATIONS}

Sustaining migratory mule deer populations in the BHU will require that suitable seasonal ranges (i.e., winter, transition, summer) be maintained and migration routes remain functional. The 116,494 GPS locations we collected from 47 different mule deer provide a baseline data set that objectively and accurately identifies seasonal ranges and migration routes of mule deer in the ARPA prior to full-scale gas development. We encourage agencies and industry to consider and incorporate this information in development plans and management strategies associated with the ARPA.

The mapping options available with 116,494 deer locations are unlimited, and as such, we only included the most relevant maps in this report. However, we strongly encourage agencies and industry to utilize the GPS/GIS database for mapping projects that may assist them with site specific development plans (e.g., transportation plans, pipelines, well pad placement) and management prescriptions (e.g., habitat improvement projects, conservation easements, fencing modifications, highway crossings) in the ARPA. The database allows for easy mapping and evaluation of an assortment of attribute data for each GPS location, including date, time, latitude, longitude, UTM coordinates, animal ID, herd unit, hunt area, seasonal range, and land ownership. Additionally, the GPS database provides an excellent source of pre-development information, should any development-phase monitoring programs be implemented to assess potential impacts to mule deer distribution or movement patterns. 


\subsection{LITERATURE CITED}

Bowyer, R. T. 1984. Sexual segregation in southern mule deer. Journal of Mammalogy 65:410-417.

Bowyer, R. T., J. G. Kie, and V. Van Ballenberghe. 1996. Sexual segregation in black-tailed deer: effects of scale. Journal of Wildlife Management 60:10-17.

Bureau of Land Management. 1998. Southwest Wyoming Resource Evaluation Report and Recommendations. USDI-BLM, Wyoming State Office, Cheyenne, Wyoming.

Bureau of Land Management. 2005.Draft Environmental Impact Statement Atlantic Rim Natural Gas Field Development Project. Rawlins Field Office, Rawlins, Wyoming.

Bureau of Land Management. 2006. Final Environmental Impact Statement Atlantic Rim Natural Gas Field Development Project. Rawlins Field Office, Rawlins, Wyoming.

Clements, C. D. and J. A. Young. 1997. A viewpoint: Rangeland health and mule deer habitat. Journal of Range Management 50:129-138.

DeBolt, B. L. 2000. Habitat use and diet selection of sympatric mule deer and elk in southcentral Wyoming. M. S. Thesis, University of Wyoming, Laramie, Wyoming.

Di Orio, A. P., R. Callas, and R. J. Schaefer. 2003. Performance of two GPS telemetry collars under different habitat conditions. Wildlife Society Bulletin 31:372-379.

Horne, J. S., E. O. Garton, S. M. Krone, and J. S. Lewis. 2007. Analyzing animal movements using Brownian Bridges. Ecology, In Press.

Kaplan, E. L. and P. Meier. 1985. Nonparametric estimation from incomplete observations. Journal of American Statistical Association 53:457-581.

King, M. M. and H. D. Smith. 1980. Differential habitat utilization by the sexes of mule deer. Great Basin Naturalist 40:273-281.

McCullough, D. R. 1985. Long range movements of large terrestrial animals. Contributions in Marine Science Supplement 27: 444465.

Main, M. B. and B. E. Coblentz. 1996. Sexual segregation in Rocky Mountain mule deer. Journal of Wildlife Management 60:497-507.

Nelson, R., G. Stout, L. Myers, and R. Straw. 1994. Baggs mule deer crucial winter range analysis. Wyoming Game and Fish Department, Cheyenne, Wyoming.

Porter, M. A. 1999. Spatial relationships between sympatric mule deer and elk in southcentral Wyoming. M. S. Thesis, University of Wyoming, Laramie, Wyoming.

Sawyer, H., F. Lindzey, and D. McWhirter. 2005. Mule deer and pronghorn migration in western Wyoming. Wildlife Society Bulletin 33:1266-1273.

Sawyer, H., R. Nielson, F. Lindzey, and L. McDonald. 2006a. Winter habitat selection of mule deer before and during development of a natural gas field. Journal of Wildlife Management 70:396-403.

Sawyer, H., R. Nielson, D. Strickland, and L. McDonald. 2006b. 2006 Annual Report. Sublette Mule Deer Study (Phase II): Long-term monitoring plan to assess potential impacts of energy development on mule deer in the Pinedale Anticline Project Area. Western Ecosystems Technology, Inc., Cheyenne, Wyoming.

Sheehy, D. P. and A. H. Winward. 1981. Relative palatability of seven Artemisia taxa to mule deer and sheep. Journal of Range Management 34:397-399.

Short, H.L. 1981. Nutrition and Metabolism. Pages 99-127 In O.C. Wallmo, editor, Mule and Black-tailed Deer of North America. University of Nebraska Press, Lincoln, Nebraska. 
Unsworth, J. W., D. F. Pac, G. C. White, R. M. Bartmann.1999. Mule deer survival in Colorado, Idaho, and Montana. Journal of Wildlife Management 63:315-326.

Wambolt, C. L. 1996. Mule deer and elk foraging preference for 4 sagebrush taxa. Journal of Range Management 49:499-503.

White, G. C., R. A. Garrott, R. M. Bartmann, L. H. Carpenter, and A. W. Alldredge. 1987. Survival of mule deer in northwest Colorado. Journal of Wildlife Management 51:852-589.

White, G. C., A. F. Reeve, F. G. Lindzey, and K. P. Burnham. 1996. Estimation of mule deer winter mortality from age ratios. Journal of Wildlife Management 60:37-44.

Woolley, T. 2005. 2005 Job Completion Report for the Baggs Mule Deer Herd Unit. Wyoming Game and Fish Department, Cheyenne, Wyoming. 
